\title{
Effects of alkali treatment of wheat straw on intake and microbial protein synthesis in cattle
}

\author{
BY N. SRISKANDARAJAH AND R. C. KELLAWAY \\ Department of Animal Husbandry, University of Sydney, Camden, \\ New South Wales, 2570, Australia
}

(Received 20 May 1983 - Accepted 14 October 1983)

\begin{abstract}
1. Effects of sodium hydroxide treatment on intake and digestion of straw organic matter (OM), and microbial protein synthesis were examined in comparison with untreated and treated straws.

2. Intakes (kg dry matter (DM)/d) of untreated, $\mathrm{NaOH}$ - and sodium carbonate-treated straws were 5.21, $7 \cdot 04$ and 6.48 respectively and intakes $(\mathrm{kg} / \mathrm{d})$ of digestible organic matter (DOM) for the respective diets were 2.57 , 3.73 and 2.98 respectively. $\mathrm{NaOH}$-treated straw ranked higher than untreated straw in intakes of DM and DOM $(P<0 \cdot 01)$.

3. The proportion of DOM intake that was apparently digested in the rumen was $0.74,0.77$ and 0.66 on untreated, $\mathrm{NaOH}$ - and $\mathrm{Na}_{2} \mathrm{CO}_{3}$-treated straws respectively.

4. Although the amount of bacterial $\mathrm{N}$ leaving the abomasum was higher with $\mathrm{NaOH}$-treated than with untreated straw $(74.6$ v. $56.8 \mathrm{~g} / \mathrm{d}, P<0.01)$, efficiencies of bacterial $\mathrm{N}$ synthesis were not different between these treatments $(28.6$ v. $31.5 \mathrm{~g}$ bacterial $\mathrm{N} / \mathrm{kg} \mathrm{OM}$ apparently digested, $P>0.05)$.

5. The live-weight gain which the $\mathrm{NaOH}$-treated straw could support was predicted to be $350 \mathrm{~g} / \mathrm{d}$ and it was concluded that a protein supplement would have provided further increase in production in diets based on $\mathrm{NaOH}$-treated straw.
\end{abstract}

Alkali treatment of cereal straw is known to increase its edibility substantially, and this is associated with increases in potential digestibility and rate of digestion, and reductions in retention time of cell walls in the rumen (Thiago et al. 1979). Efficiency of microbial protein synthesis in the rumen is sometimes positively correlated with liquid dilution rates in the rumen when these are increased by infusing salts into the rumen (Harrison et al. 1975, 1976). However, Mathers \& Miller (1981), in a review of published work, found no such correlation. Crawford et al. (1980) found that efficiency of microbial protein synthesis was correlated more with solid flow-rates than liquid flow-rates, which might be expected when a high proportion of bacteria leave the rumen attached to solid feed particles.

In the present experiment we investigated the possibility that increases in liquid dilution rate due to high sodium intakes, and reductions in solid retention time in the rumen due to alkali treatment, would increase efficiency of microbial protein synthesis in the rumen.

\section{EXPERIMENTAL}

\section{Animals and management}

Four 3-year-old Friesian steers (average live weight $348 \mathrm{~kg}$ ), fitted with simple cannulas in the rumen, abomasum and terminal ileum, were tethered in individual pens.

\section{Diets and feeding regimen}

Untreated-straw diet (U) was prepared by spraying chaffed wheat straw with urea, sulphuric acid and phosphoric acid to supply $17 \cdot 8,1 \cdot 2$ and 3.0 g nitrogen, sulphur and phosphorus $/ \mathrm{kg}$ straw respectively. Sodium hydroxide-treated straw (T) and sodium carbonate-treated straw (C) were prepared by treating in the same way as $\mathrm{U}$ followed by application of $50 \mathrm{~g} \mathrm{NaOH}$ and $66 \mathrm{~g} \mathrm{Na}_{2} \mathrm{CO}_{3} / \mathrm{kg}$ straw for $\mathrm{T}$ and $\mathrm{C}$ respectively, as aqueous solutions to obtain a final moisture content of $200 \mathrm{~g} / \mathrm{kg}$. Straw was treated in $50 \mathrm{~kg}$ batches in a paddle mixer fitted 
with spray nozzles and was stored in hessian bags for a minimum of $5 \mathrm{~d}$ before feeding. Straw was given in buckets ad lib., at $3 \mathrm{~h}$ intervals from 09.00 hours. Voluntary intake was measured during a period of $10 \mathrm{~d}$ following a preliminary period of $14 \mathrm{~d}$. U, T and $\mathrm{C}$ contained (g/kg DM) respectively $20 \cdot 7,18.7$ and $18.0 \mathrm{~N}, 59 \cdot 4,56.8$ and $61 \cdot 2$ lignin, 803.9, 699.6 and 731.0 neutral-detergent fibre (NDF) and 67.9, 103.5 and 101.0 ash.

\section{Digesta markers and sampling}

The dual markers used were acid-detergent lignin for the solid phase and chromium-EDTA for the liquid phase. Cr-EDTA, prepared according to Binnerts et al. (1968), was infused into the rumen via the cannula during the last $10 \mathrm{~d}$ of each $24 \mathrm{~d}$ period to supply $280 \mathrm{mg}$ $\mathrm{Cr} / \mathrm{kg}$ straw. During the last $3 \mathrm{~d}$ of each period, rumen, abomasal and ileal samples and 'grab' faecal samples were collected at $09.45,13.30$ and 17.15 hours, bulked, frozen and stored at $-10^{\circ}$. At the end of each period, Cr-EDTA infusion was terminated and rumen fluid sampled five times in the following $24 \mathrm{~h}$ for $\mathrm{Cr}$ analysis and $\mathrm{pH}$ measurement. Feed samples were collected daily and bulked.

\section{Bacterial N}

Rumen samples collected during the experiment were used to isolate rumen bacteria, according to Hutton et al. (1971). Two isolates were prepared for each dietary treatment and analysed for 2,6-diaminopimelic acid (DAP) and N. Mean (with SE) values (mg DAP/g $\mathrm{N})$ of $42 \cdot 1(3 \cdot 10), 42 \cdot 7(3.93)$ and $49 \cdot 3(0 \cdot 46)$ were determined on bacteria from animals on treatments $U, T$ and $C$ respectively. A mean value of $44.7 \mathrm{mg} \mathrm{DAP} / \mathrm{g} \mathrm{N}$ was used to calculate the proportion of abomasal $\mathrm{N}$ present as bacterial $\mathrm{N}$.

\section{Sample preparation and chemical analyses}

Rumen samples were filtered through cloth to remove coarse particles, acidified with $\mathrm{H}_{2} \mathrm{SO}_{4}$ to $\mathrm{pH} 2$ and stored at $-10^{\circ}$ for volatile fatty acid (VFA) and ammonia analyses. Abomasal and ileal samples were centrifuged at $2400 \mathrm{~g}$ for $20 \mathrm{~min}$ to obtain liquid-rich fractions. Total abomasal and ileal samples and corresponding liquid-rich fractions, feed and faeces samples were analysed for DM, by drying in a forced-draught oven at $50^{\circ}$, and $\mathrm{OM}$, by igniting samples in a muffle furnace at $555^{\circ}$ overnight. $N$ was analysed by a micro-Kjeldahl technique and NDF and lignin by the technique of Goering \& Van Soest (1970).

Total digesta and liquid-rich fractions of abomasal and ileal samples were subjected to wet digestion by a procedure in which a $0.5 \mathrm{~g}$ sample was digested in a boiling-tube at $20^{\circ}$ overnight with $5 \mathrm{ml}$ concentrated nitric acid, after which $1 \mathrm{ml} \mathrm{H}_{2} \mathrm{SO}_{4}$ and $3 \mathrm{ml}$ perchloric acid were added and the tubes heated to boiling for $3 \mathrm{~h}$ with a loose-fitting glass stopper to assist condensation. $\mathrm{Cr}$ concentration in the digesta was measured by atomic absorption spectrophotometry. Feed, total abomasal and ileal samples and faecal samples were analysed for acid-detergent lignin. $\mathrm{Cr}$ content in rumen fluid was measured by atomic absorption spectrophotometry after centrifuging the sample at $2400 \mathrm{~g}$ for $20 \mathrm{~min}$. Total abomasal digesta were analysed for DAP by ion-exchange chromatography following $24 \mathrm{~h}$ hydrolysis in $6 \mathrm{M}$-hydrochloric acid at $136^{\circ}$. Flows of abomasal and ileal digesta were calculated from marker concentrations using eqns 1-3 from Faichney (1975).

\section{Statistical analysis}

A changeover design was employed with four animals and six periods. For the first three periods the treatments were offered in a $3 \times 3$ Latin-square arrangement with an extra column. This was repeated for the final three periods. Treatment means were compared on the basis of the least significant difference (Steel \& Torrie, 1960). 
Table 1. Digestion of organic matter $(O M)$ in the stomach and intestines of cattle given untreated $(U)$, sodium hydroxide-treated $(T)$ and sodium carbonate-treated $(C)$ wheat straw

\begin{tabular}{lcccc}
\hline \hline Treatment... & $\mathrm{U}$ & $\mathrm{T}$ & $\mathrm{C}$ & SED \\
\hline DM intake $(\mathrm{g} / \mathrm{d})$ & $5208^{\mathrm{a}}$ & $7040^{\mathrm{b}}$ & $6484^{\mathrm{b}}$ & $279 \cdot 1$ \\
OM intake $(\mathrm{g} / \mathrm{d})$ & $4852^{\mathrm{a}}$ & $6325^{\mathrm{b}}$ & $5834^{\mathrm{b}}$ & $252 \cdot 9$ \\
Leaving abomasum $(\mathrm{g} / \mathrm{d})$ & $2983^{\mathrm{a}}$ & $3177^{\mathrm{a}}$ & $3474^{\mathrm{a}}$ & $265 \cdot 1$ \\
Leaving ileum $(\mathrm{g} / \mathrm{d})$ & $2623^{\mathrm{a}}$ & $2967^{\mathrm{ab}}$ & $3091^{\mathrm{b}}$ & $174 \cdot 5$ \\
In faeces $(\mathrm{g} / \mathrm{d})$ & $2293^{\mathrm{a}}$ & $2319^{\mathrm{ab}}$ & $2648^{\mathrm{b}}$ & $139 \cdot 6$ \\
Apparent OM digestibility & $0 \cdot 53^{\mathrm{a}}$ & $0 \cdot 59^{\mathrm{b}}$ & $0 \cdot 51^{\mathrm{a}}$ & $0 \cdot 020$ \\
Proportion of DOM & & & & \\
apparently digested in & & & & \\
Stomach & $0 \cdot 74^{\mathrm{ab}}$ & $0 \cdot 77^{\mathrm{a}}$ & $0 \cdot 66^{\mathrm{b}}$ & $0 \cdot 039$ \\
Small intestine & $0 \cdot 14^{\mathrm{a}}$ & $0 \cdot 17^{\mathrm{a}}$ & $0 \cdot 26^{\mathrm{b}}$ & $0 \cdot 039$ \\
Hind gut & $0 \cdot 12$ & $0 \cdot 06$ & $0 \cdot 08$ & 0.023 \\
DOM intake (g/d) & $2569^{\mathrm{a}}$ & $3734^{\mathrm{b}}$ & $2980^{\mathrm{a}}$ & $230 \cdot 1$ \\
DOMD & $0 \cdot 49^{\mathrm{ab}}$ & $0 \cdot 53^{\mathrm{a}}$ & $0 \cdot 46^{\mathrm{b}}$ & $0 \cdot 018$ \\
\hline \hline
\end{tabular}

DM, dry matter; DOM, digestible organic matter; DOMD, digestible organic matter in dry matter; SED, standard error of difference.

a, b Values, within horizontal rows, with unlike superscripts differed significantly $(P<0 \cdot 05)$.

Table 2. Digestion of dietary nitrogen and synthesis of bacterial $N$ in stomach and intestines of cattle given untreated $(U)$, sodium hydroxide-treated $(T)$ and sodium carbonate-treated $(C)$ wheat straw

\begin{tabular}{|c|c|c|c|c|}
\hline Treatment... & $\mathrm{U}$ & $\mathrm{T}$ & $\mathrm{C}$ & SED \\
\hline $\mathrm{N}$ intake $(\mathrm{g} / \mathrm{d})$ & $109 \cdot 0^{\mathrm{n}}$ & $127 \cdot 4^{a}$ & $114 \cdot 2^{\mathrm{a}}$ & 8.54 \\
\hline Leaving abomasum & $71 \cdot 6^{\mathrm{a}}$ & $89.9^{b}$ & $90 \cdot 2^{b}$ & 6.04 \\
\hline Leaving ileum & $33 \cdot 7^{\mathrm{a}}$ & $35.5^{\mathrm{a}}$ & $39 \cdot 6^{\mathrm{a}}$ & 3.88 \\
\hline In faeces & $23 \cdot 0^{a}$ & $27 \cdot 3^{\mathrm{b}}$ & $26.9^{\mathrm{b}}$ & 1.54 \\
\hline \multicolumn{5}{|l|}{ Proportion of bacterial } \\
\hline $\mathrm{N}$ in abomasum & $0 \cdot 80^{\mathrm{ab}}$ & $0.83^{b}$ & $0.74^{\mathrm{z}}$ & 0.040 \\
\hline $\begin{array}{l}\text { abomasum } \\
\text { Bacterial N (g/kg OM }\end{array}$ & $56 \cdot 8^{\mathrm{a}}$ & $74 \cdot 6^{b}$ & $66 \cdot 5^{\mathrm{ab}}$ & $4 \cdot 77$ \\
\hline $\begin{array}{l}\text { apparently digested } \\
\text { in the rumen) }\end{array}$ & $31 \cdot 5$ & 28.6 & $34 \cdot 1$ & 3.94 \\
\hline $\mathrm{N}$ digestibility & $0.79^{\mathrm{a}}$ & $0.78^{\mathrm{ab}}$ & $0.76^{b}$ & 0.011 \\
\hline
\end{tabular}

SED, standard error of difference; OM, organic matter.

$\mathrm{a}, \mathrm{b}$ Values, within horizontal rows, with unlike superscripts differed significantly $(P<0 \cdot 05)$.

\section{RESULTS}

Animals remained in good health throughout the experiment. Most experimental periods were longer than the planned $24 \mathrm{~d}$ because of difficulties in maintaining intakes of straw within $5 \%$ of a mean established before each sampling period.

Values pertaining to digestion of $\mathrm{OM}$ are summarized in Table 1. Intakes of $\mathrm{OM}$ for $\mathrm{NaOH}$ and $\mathrm{Na}_{2} \mathrm{CO}_{3}$-treated straws were 24 and $17 \%$ higher respectively, than for intreated straw. These differences in intake were not reflected in OM flows through the abomasum and ileum which were similar between treatments, indicating increased rumen apparent digestion of 
Table 3. Concentrations of volatile fatty acids $(V F A)$ and ammonia in the rumen and fractional rate of water outflow from the rumen in cattle given untreated $(U)$, sodium hydroxide-treated $(T)$ and sodium carbonate-treated $(C)$ wheat straw

\begin{tabular}{|c|c|c|c|c|}
\hline Treatment... & $\mathbf{U}$ & $\mathbf{T}$ & $\mathrm{C}$ & SED \\
\hline Total VFA (mmol/l) & $76 \cdot 4^{\mathrm{a}}$ & $84 \cdot 6^{\mathrm{b}}$ & $83 \cdot 8^{\mathrm{ab}}$ & $3 \cdot 61$ \\
\hline \multicolumn{5}{|c|}{ Proportions of individual VFA } \\
\hline Acetic & $0.719^{\mathrm{a}}$ & $0 \cdot 728^{\mathrm{a}}$ & $0.732^{\mathrm{a}}$ & 0.0934 \\
\hline Propionic & $0 \cdot 206^{\mathrm{a}}$ & $0 \cdot 191^{\mathrm{a}}$ & $0 \cdot 190^{\mathrm{a}}$ & 0.0662 \\
\hline iso-Butyric & $0.012^{\mathrm{a}}$ & $0.011^{\mathrm{a}}$ & $0.012^{\mathrm{a}}$ & 0.0187 \\
\hline n-Butyric & $0.052^{\mathrm{a}}$ & $0.055^{\mathrm{a}}$ & $0.052^{\mathrm{a}}$ & 0.0287 \\
\hline iso-Valeric & $0.009^{\mathrm{a}}$ & $0.010^{\mathrm{a}}$ & $0.010^{\mathrm{a}}$ & 0.0125 \\
\hline $\mathrm{n}$-Valeric & $0.004^{\mathrm{a}}$ & $0.006^{\mathrm{a}}$ & $0 \cdot 004^{a}$ & 0.0077 \\
\hline Ammonia $(\mathrm{mmol} / \mathrm{l})$ & $17 \cdot 3^{\mathrm{a}}$ & $14 \cdot 4^{\mathrm{ab}}$ & $13 \cdot 2^{\mathrm{b}}$ & 1.74 \\
\hline Water outflow rate $(/ \mathrm{h})$ & $0.066^{\mathrm{a}}$ & $0.093^{\mathrm{b}}$ & $0.086^{\mathrm{ab}}$ & 0.0125 \\
\hline
\end{tabular}

SED, standard error of difference.

a, b Values, within horizontal rows, with unlike superscripts differed significantly $(P<0.05)$.

$\mathrm{OM}$ on the two treated diets, although $\mathrm{OM}$ excreted in the faeces was significantly higher on the $\mathrm{Na}_{2} \mathrm{CO}_{3}$-treated diet $(P<0.05)$. Digestible organic matter in DM (DOMD) was highest on the $\mathrm{NaOH}$-treated straw $(P<0.05)$. The proportion of DOM digested in the stomach was higher with $\mathrm{NaOH}$-treated straw than with the untreated and $\mathrm{Na}_{2} \mathrm{CO}_{3}$-treated straws.

Differences in intake of $\mathbf{N}$ were a reflection of the differences in intake of straw, and almost all the $\mathrm{N}$ was in the form of urea applied on the straw (Table 2). There were substantial losses of $\mathbf{N}$ in the stomach, the loss in relation to intake being highest for the untreated straw. Abomasal flow of $\mathrm{N}$ was highest on the treated diets and the ileal flow of $\mathrm{N}$ was similar, indicating greater digestion of $\mathbf{N}$ in the small intestine on the two treated diets $(P<0.05)$.

Bacterial $\mathbf{N}$ as a proportion of total abomasal $\mathbf{N}$ was found to be highest in the $\mathrm{NaOH}$-treated diet $(P<0.05)$. Despite the higher level of bacterial $\mathrm{N}$ in abomasal $\mathrm{N}$, efficiency of microbial protein synthesis, estimated as g bacterial N/kg OM apparently digested, was not different between diets $(P>0.05)$, the mean value being 31 . Rumen ammonia levels were significantly lower on the treated straw diets compared with the untreated control $(P<0.05)$ (Table 3).

Total VFA concentration was higher on the treated straw diets than the untreated, but the difference was significant only with the $\mathrm{NaOH}$-treated diet $(P<0.05$; Table 3$)$. Proportions of individual VFA did not differ significantly between treatments. Dilution rate in the rumen was higher on treated straw than untreated straw $(P<0.05)$.

\section{DISCUSSION}

To differentiate between osmotic effects of $\mathrm{NA}^{+}$and alkaline effects of $\mathrm{OH}^{-}$in $\mathrm{NaOH}$, an equimolar amount of $\mathrm{Na}^{+}$in $\mathrm{Na}_{2} \mathrm{CO}_{3}$ was used. $\mathrm{Na}_{2} \mathrm{CO}_{3}$ itself has weak alkaline properties. If $\mathrm{Na}_{2} \mathrm{CO}_{3}$ proved to be as effective as $\mathrm{NaOH}$ in improving nutritional quality of straw, it would be a much safer chemical to handle than $\mathrm{NaOH}$ in farm practice. However, reports on the use of $\mathrm{Na}_{2} \mathrm{CO}_{3}$ are conflicting. Chandra \& Jackson (1971) measured digestibility in situ and found that $\mathrm{Na}_{2} \mathrm{CO}_{3}$ was much less effective than $\mathrm{NaOH}$, but of some benefit when mixed with $\mathrm{NaOH}$ in equal proportions. Coombe \& Dove (1978) measured digestibility in vitro and obtained improvement in digestibility of oat straw, from 47 to $71 \%, 7 \mathrm{~d}$ after treatment with $80 \mathrm{~g} \mathrm{Na}_{2} \mathrm{CO}_{3} / \mathrm{kg}$. It is known that responses to $\mathrm{NaOH}$ treatment of straw are overestimated by in vitro methods in comparison with in vivo (Levy et al. 1977; Smith 
et al. 1981). $\mathrm{Na}_{2} \mathrm{CO}_{3}$-treated straw ranked between untreated and $\mathrm{NaOH}$-treated straw in terms of DOMD and digestible organic matter intake (DOMI), but the differences were not significant. It appears that the strong alkaline property of $\mathrm{NaOH}$ was responsible for the improvement in nutritive value of the straw achieved in the present study.

\section{Voluntary intake}

An important change following $\mathrm{NaOH}$ treatment of straw is the large increase in voluntary intake by the animal (Jackson, 1977). The $24 \%$ increase in OM intake of straw following $\mathrm{NaOH}$ treatment obtained in the present study was significant, but smaller than increases of 39 and $102 \%$ obtained in earlier studies by Sriskandarajah et al. (1982) and Thiago et al. (1979) respectively. This smaller response to $\mathrm{NaOH}$ treatment may be related to the maturity of the animal, the animals used in the present study being mature, 36-month-old bullocks. Another factor was that these cannulated animals had been maintained on low-quality roughage diets for very long periods of time previously, and the adaptation of the animals to these diets may have resulted in higher intakes of the basal diet, thereby reducing the difference in intake between $\mathrm{NaOH}$-treated and untreated straws. However, over a period of 8 weeks, Sriskandarajah \& Kellaway (1982) found that the difference in intake between $\mathrm{NaOH}$-treated and untreated straws remained constant.

\section{$O M$}

The higher intake of $\mathrm{NaOH}$-treated straw coupled with a higher apparent digestion of $\mathrm{OM}$ in the alimentary tract resulted in DOMI being $46 \%$ higher than on untreated straw, whereas DOMI of $\mathrm{Na}_{2} \mathrm{CO}_{3}$-treated straw was only $19 \%$ higher than that of untreated straw. DOMD of the three diets followed the same ranking with $\mathrm{NaOH}$ - and $\mathrm{Na}_{2} \mathrm{OH}_{3}$-treated diets, being 21 and $6 \%$ higher respectively than the untreated control.

Higher apparent digestion of $\mathrm{OM}$ in the $\mathrm{NaOH}$-treated diet compared with the control diet was attributable to greater digestion of $\mathrm{OM}$ in both the rumen and hind-gut. Redman et al. (1980) reported similar findings with cattle given $\mathrm{NaOH}$-treated oat straw. Increase in the proportion of OM digested in the rumen can be related to increases in potential digestibility and rate of digestion, particularly of cell walls, following $\mathrm{NaOH}$ treatment (Coombe et al. 1979; Thiago et al. 1979). As well as increasing the proportion of potentially digestible $\mathrm{OM}, \mathrm{NaOH}$ treatment increases the passage rate of undigested material from the rumen (Thiago et al. 1979), more of which would be digestible. Indeed, this is confirmed by observations in Table 1 which show that $0.13,0.22$ and 0.14 of OM leaving the ileum was digested in the hind-gut on treatments $\mathrm{U}, \mathrm{T}$ and $\mathrm{C}$ respectively.

OM apparently digested in the small intestine, calculated from $O M$ flows at the abomasum and ileum (Table 1), was 360,210 and $383 \mathrm{~g} / \mathrm{d}$ on treatments $\mathrm{U}, \mathrm{T}$ and $\mathrm{C}$ respectively. The values for $\mathrm{T}$ and $\mathrm{C}$ were low in relation to $\mathrm{N}$ apparently absorbed in the small intestine. If $\mathrm{N}$ apparently absorbed in the small intestine (Table 3) is assumed to be largely microbial, with an OM:N value of 10:1, calculated values for $\mathrm{OM}$ apparently digested in the small intestine derived from $N$ flows were 379,544 and $506 \mathrm{~g} / \mathrm{d}$ on treatments $\mathrm{U}, \mathrm{T}$ and $\mathrm{C}$ respectively. These values appear more reasonable than those calculated directly from OM flows, although $t$ tests on differences between the three pairs of estimates were not significant $(P>0.05)$ and would suggest that endogenous secretions into the small intestine had a lower N:OM value than was observed in abomasal contents.

\section{Cell wall}

Significantly higher total VFA concentration with trends towards an 'acetate'-type fermentation as a result of $\mathrm{NaOH}$-treatment of the straw are in line with increased fermentative activity in the rumen and increase in cell wall digestion. There was no 
significant relationship between molar proportions of acetate or propionate and dilution rate as obtained by Harrison et al (1975).

$N$

Adequate levels of rumen-degradable $N(R D N)$ in all diets were ensured by spraying urea on the straw at the rate of $38 \mathrm{~g} / \mathrm{kg}$ straw. This was reflected in $\mathrm{NH}_{3}$ levels in the rumen ranging from 13 to $17 \mathrm{mmol} / \mathrm{l}$. Leibholz \& Kellaway (1980) suggested that a rumen $\mathrm{NH}_{3}$ concentration of $20 \mathrm{mmol} / 1$ was optimal for microbial protein synthesis, and achieved this by spraying $28 \mathrm{~g}$ urea $/ \mathrm{kg}$ straw. Despite the higher level of application of urea in the present study, rumen $\mathrm{NH}_{3}$ levels were somewhat lower than those found by Leibholz \& Kellaway (1980), indicating that the balance between production and utilization of $\mathrm{NH}_{3}$ in the rumen varied with the quality of the basal diet. A higher rumen $\mathrm{NH}_{3}$ level in the untreated compared to the treated diets is consistent with the larger difference between intake and abomasal flow of $\mathrm{N}$ and the smaller extent of $\mathrm{OM}$ digestion in the rumen.

\section{Microbial protein synthesis}

When diets have a high value of RDN: undegraded $\mathrm{N}$ (UDN), as in the present experiment, a high proportion of abomasal $\mathrm{N}$ is microbial. This was observed in the present study where $0.74-0.83$ of the $\mathrm{N}$ flowing through the abomasum was estimated to be of bacterial origin, using DAP as the bacterial marker. In terms of crude protein $(\mathrm{N} \times 6.25)$ available for digestion in the intestines, the bacterial contribution was 32 and $18 \%$ higher on $\mathrm{NaOH}$-treated straw and $\mathrm{Na}_{2} \mathrm{CO}_{3}$-treated straw respectively, than on untreated straw. Although absolute quantities of bacterial protein reaching the intestines were increased by treatment of the straw, relative efficiencies of bacterial protein synthesis were not significantly different between treatments. The mean value of $31 \mathrm{~g}$ bacterial $\mathrm{N} / \mathrm{kg} \mathrm{OM}$ apparently digested in the rumen is similar to the value of 30 adopted as the mean for all diets by the Agricultural Research Council (1980). Hogan \& Weston (1971) reported a range of 32-55 g N/kg OM apparently digested in the rumen of sheep that were given ground $\mathrm{NaOH}$-treated wheaten straw at three levels of feeding. Large variations in the efficiency of microbial protein synthesis have been reported in the literature (see Agricultural Research Council, 1980), due in part to the technical problems associated with sampling of digesta and the type of microbial markers used in the studies. Variations could also be attributed to changes in feeding conditions which alter bacterial maintenance requirements as a proportion of their total energy requirements or changes which result in partial uncoupling of the fermentation process due to specific deficiencies of essential nutrients such as $\mathbf{N}$ or $\mathbf{S}$. Spraying urea on the straw provided a frequent supply of $\mathbf{N}$ coupled with the intake of DOM. However, increases in efficiency of microbial protein synthesis which may have been achieved by addition of a protein supplement, particularly with $\mathrm{NaOH}$-treated straw, cannot be ruled out. Meggison (1979) achieved substantial increases in efficiency of microbial protein synthesis in cattle of from 29 to $42 \mathrm{~g}$ microbial $\mathrm{N} / \mathrm{kg}$ OM apparently digested in the rumen, on a diet of alkali-treated straw and ground barley, by supplying urea twenty-four times daily instead of twice daily. It is possible that protein supply from ground barley in that study permitted the large increase when supply of RDN was made more frequent. On the other hand, it could be argued that the balance in energy release arising from the rapid digestion of barley and slow digestion of alkali-treated straw provided better synchronization with the supply of RDN from frequent urea feeding which led to a greater efficiency of microbial synthesis in Meggison's (1979) study.

Increased efficiency of microbial growth has been shown to be related to increased dilution rate of rumen fluid (see Harrison \& McAllan, 1980). A 50\% increase in dilution rate brought about by $\mathrm{NaOH}$-treatment of the straw in the present experiment was accompanied 
by a decrease in efficiency of microbial protein synthesis, although the latter difference was not significant. A similar trend was observed by Crawford et al. (1980) in a continuous-culture system. Mathers \& Miller (1981) reported that there was no relationship between dilution rate and microbial growth efficiency in their own study and in a review of other published values. It may be that the operating dilution rates were already high in these studies, including the present one, and further changes in dilution rate were not substantial enough to bring about measurable changes in efficiency. Furthermore, liquid dilution rate, as measured in these studies, is not indicative of the turnover of micro-organisms attached to particulate matter and their influence on efficiency of microbial synthesis. Forsberg \& Lam (1977) found that $75 \%$ of microbial ATP detected in rumen contents was associated with the particulate fraction. Importance of particle-adherent bacteria in cell wall digestion has been clearly demonstrated (Akin, 1979; Cheng \& Costerton, 1980) and it has been shown that retention times of solute markers such as Cr-EDTA may not be appropriate values for bacteria (Faichney \& Griffiths, 1978). In their review of published in vivo estimates, Mathers \& Miller (1981) showed a discrepancy between specific growth rate of rumen micro-organisms and dilution rate based on solute markers. It is therefore evident that in in vivo systems, solid passage rate may be more closely related to turnover and efficiency of synthesis of micro-organisms in the rumen than liquid dilution rate. Indeed, Crawford et al. (1980) maintained different solid and liquid dilution rates in a continuous-culture system and observed that microbial cell yields increased more with solid passage rate than with liquid dilution rate.

Digestibility of total $\mathrm{N}$ in the intestines in the present study was 0.69 . Of the total $\mathrm{N}$ disappearing in the intestines, $0.14-0.22$ disappeared in the large intestine. This amounted to $9-13 \mathrm{~g} \mathrm{~N} / \mathrm{d}$, which falls within the ranges quoted by Smith (1975) and Ulyatt et al. (1975) for hind-gut digestion of $\mathrm{N}$. In the absence of definite proof of amino acid absorption from the caecum, the major loss of $\mathrm{N}$ in the hind-gut would be as absorption of $\mathrm{NH}_{3}$ produced by microbial fermentation.

Based on DOMI values for the three diets, daily intakes of metabolizable energy can be calculated to be 37, 56 and $45 \mathrm{MJ}$ for the untreated, $\mathrm{NaOH}$-treated and $\mathrm{Na}_{2} \mathrm{CO}_{3}$-treated straw diets, which should be capable of supporting growth rates of $<0,350$ and $113 \mathrm{~g} / \mathrm{d}$ respectively (Ministry of Agriculture, Fisheries \& Food, 1975). The level of intake of the $\mathrm{NaOH}$-treated diet $\left(87 \mathrm{~g} / \mathrm{kg}\right.$ live weight $(\mathrm{W})^{0.75}$ per d) in the present study was lower than the $92 \mathrm{~g} / \mathrm{kg} \mathrm{W}^{0.75}$ per d intake obtained with younger animals in an earlier study (Sriskandarajah et al. 1982) in which growth rates of $334 \mathrm{~g} / \mathrm{d}$ were obtained. Protein : energy value as a measure of the balance of digestible nutrients from a diet, calculated for the $\mathrm{NaOH}$-treated straw diet in the present study, was $5.1 \mathrm{~g}$ digestible protein reaching the intestines/MJ metabolizable energy, assuming that 0.8 of the microbial $\mathrm{N}$ reaching the intestine was amino acid $\mathrm{N}$ with an apparent absorbability of 0.7 (Agricultural Research Council, 1980). This is lower than the value of 6.7 quoted as the average for a variety of forages (Egan \& Walker, 1973), suggesting that there was potential for increasing production from the animals on $\mathrm{NaOH}$-treated-straw diets, by supplementing the diet with a source of rumen-undegradable protein. This was demonstrated in the earlier experiment (Sriskandarajah et al. 1982) where a $500 \mathrm{~g}$ daily supplement of cottonseed meal significantly increased live-weight gain from 334 to $495 \mathrm{~g} / \mathrm{d}$ in cattle on an $\mathrm{NaOH}$-treated-straw diet. We conclude that a combination of $\mathrm{NaOH}$ treatment and urea supplementation enhances the nutritive value of poor-quality wheat straw to a diet capable of supporting moderate production, and further increases in production might be expected by giving a supplement of rumen-undegradable protein. 
The authors wish to thank Mr R. Butchers, Ms J. Playfair and Ms H. Warren for technical assistance, and Ms A. Kirby for statistical advice. The project was financed by the Australian Meat Research Committee. N. S. was a recipient of an F. H. Loxton Scholarship in the University of Sydney while on leave from the University of Peradeniya, Sri Lanka.

\section{REFERENCES}

Agricultura! Research Council (1980). The Nutrient Requirements of Ruminant Livestock. Slough: Commonwealth Agricultural Bureaux.

Akin, D. E. (1979). Journal of Animal Science 48, 701-710.

Binnerts, W. T., Van't Klooster, A. Th. \& Frens, A. M. (1968). Veterinary Record 82, 470.

Chandra, S. \& Jackson, M. G. (1971). Journal of Agricultural Science, Cambridge 77, $11-17$.

Cheng, K. J. \& Costerton, J. W. (1980). In Digestive Physiology and Metabolism in Ruminants, pp. $227-250$ [Y. Ruckebusch and P. Thivend, editors]. Lancaster: MTP Press.

Coombe, J. B., Dinius, D. A. \& Wheeler, W. E. (1979). Journal of Animal Science 49, 169-176.

Coombe, J. B. \& Dove, H. (1978). Annual Report of Division of Plant Industry, CSIRO, Australia, p. 103.

Crawford, R. J. Jr., Hoover, W. H. \& Junkins, L. L. (1980). Journal of Animal Science 51, 986-995.

Egan, A. R. \& Walker, D. J. (1973). In Proceedings of 3rd World Conference on Animal Production, pp. 551-562 [R. L. Reid, editor]. Sydney: Sydney University Press.

Faichney, G. J. (1975). In Digestion and Metabolism in the Ruminant, pp. 277-291 [I. W. McDonald and A. C. I. Warner, editors]. Armidale: University of New England Publishing Unit.

Faichney, G. J. \& Griffiths, D. A. (1978). British Journal of Nutrition 40, 71-82.

Forsberg, G. J. \& Lam, K. (1977). Applied and Environmental Microbiology 33, 528-537.

Goering, H. K. \& Van Soest, P. J. (1970). Forage Analysis: Agricultural Handbook no. 379. Washington, DC: Agricultural Research Service, United States Department of Agriculture.

Harrison, D. G., Beever, D. E., Thomson, D. J. \& Osbourn, D. F. (1975). Journal of Agricultural Science, Cambridge 85, 93-101.

Harrison, D. G., Beever, D. E., Thomson, D. J. \& Osbourn, D. F. (1976). Journal of the Science of Food and Agriculture 27, 617-620.

Harrison, D. G. \& McAllan, A. B. (1980). In Digestive Physiology and Metabolism in Ruminants, pp. 205-226 [Y. Ruckebusch and P. Thivend, editors]. Lancaster: MTP Press.

Hogan, J. P. \& Weston, R. H. (1971). Australian Journal of Agricultural Research 22, 951-962.

Hutton, K., Bailey, F. J. \& Annison, E. F. (1971). British Journal of Nutrition 25, 165.

Jackson, M. G. (1977). Animal Feed Science and Technology 2, $105-130$.

Leibholz, J. \& Kellaway, R. C. (1980). Proceedings of the Australian Society of Animal Production 13, 481.

Levy, D., Holzer, A., Neumark, H. \& Folman, Y. (1977). Animal Production 25, 27-37.

Mathers, I. C. \& Miller, E. R. (1981). British Journal of Nutrition 45, 587-604.

Meggison, P. A. (1977). Studies on NPN utilization in the bovine. PhD Thesis, University of Newcastle upon Tyne.

Ministry of Agriculture, Fisheries and Food (1975). Energy Allowances and Feeding Systems for Ruminants. Technical Bulletin no. 33. London: H.M. Stationery Office.

Redman, R. G., Kellaway, R. C. \& Leibholz, J. (1980). Proceedings of the Australian Society of Animal Production 13, 482 .

Smith, R. H. (1975). In Digestion and Metabolism in the Ruminant, pp. 399-415. [I. W. McDonald and A. C. I. Warner, editors]. Armidale: University of New England Publishing Unit.

Smith, T., Broster, W. H., Broster, V. J. \& Siviter, J. W. (1981). Journal of Agricultural Science, Cambridge 96, $159-165$.

Sriskandarajah, N. \& Kellaway, R. C. (1982). Journal of Agricultural Science, Cambridge 99, $241-248$.

Sriskandarajah, N., Kellaway, R. C. \& Leibholz, J. (1982). British Journal of Nutrition 47, 553-563.

Steel, R. G. D. \& Torrie, J. H. (1960). Principles and Procedures of Statistics. New York: McGraw-Hill.

Thiago, L. R. L., Kellaway, R. C. \& Leibholz, J. (1979). Annales de Recherches Vétérinaires 10, 329-331.

Ulyatt, M. J., Dellow, D. W., Reid, C. S. W. \& Bauchop, T. (1975). In Digestion and Metabolism in the Ruminant, pp. 119-133 [I. W. McDonald and A. C. I. Warner, editors]. Armidale: University of New England Publishing Unit.

Weston, R. H. \& Hogan, J. P. (1968). Australian Journal of Agricultural Research 19, 577-576. 